\title{
Pengaruh Zakat Produktif dan Minat Berwirausaha Terhadap Peningkatan Pendapatan Masyarakat Miskin Pada BAZNAS Kota Gorontalo
}

\author{
Andi Mardiana dan Agustin Y. Lihawa \\ Fakultas Ekonomi dan Bisnis IAIN Sultan Amai Gorontalo \\ Email: ndimardianabone1003@gmail.com
}

\begin{abstract}
In this research, writer to use quantitative method that is research wish to explain influence relationship and difference between variable $\chi_{1}$ (Zakat Earning), $\chi_{2}$ (interest of entrepreneurship) and variable Y (People Income) at baznas in Gorontalo city. The population in this research is 250 benefic of productive zakat and the samples are 71 samples. Method of sampling by random sampling. Sources of data in this study are primary data and secondary data. Zakat productive and entrepreneurial interests simultaneously have a positive and significant effect on increasing the income of poor people in Baznas KotaGorontalo. It is obtained from the test result $f$ that is fcount of 17,597 with significant level 0.000 and ftabel =3,13 with significant level 0,05, and also R Square value equal to 0,341 or $34,1 \%$. In this case means that productive and entrepreneurial zakat affect the increase in income of the poor by 34.1\%, while the rest of $65.9 \%$ influenced by other variables not examined in this study.
\end{abstract}

Keywords: productive zakat, entrepreneurship, income.

\begin{abstract}
Abstrak
Dalam penelitian ini, penulis menggunakan metode kuantitatif yaitu penelitian yang ingin menjelaskan pengaruh hubungan dan perbedaan antara variabel $X_{1}$ (Penghasilan Zakat), X2 (minat berwirausaha) dan variabel Y (Pendapatan Orang) di baznas di kota Gorontalo. Populasi dalam penelitian ini adalah 250 orang yang mendapat manfaat dari zakat produktif dan sampelnya adalah 71 sampel. Metode pengambilan sampel dengan random sampling. Sumber data dalam penelitian ini adalah data primer dan data sekunder. Zakat yang produktif dan berwirausaha secara simultan memiliki pengaruh positif dan signifikan terhadap peningkatan pendapatan orang miskin di Baznas KotaGorontalo. Hal ini diperoleh dari hasil uji $f$ yaitu fcount 17,597 dengan taraf signifikan 0,000 dan ftabel = 3,13 dengan taraf signifikan 0,05, dan juga $\mathrm{R}$ Square value sebesar 0,341 atau 34,1\%. Dalam hal ini berarti zakat produktif dan wirausaha mempengaruhi peningkatan pendapatan orang miskin sebesar 34,1\%, sedangkan sisanya sebesar 65,9\% dipengaruhi oleh variabel lain yang tidak diteliti dalam penelitian ini.
\end{abstract}

Kata Kunci: Zakat Produktif, Kewirausahaan, dan Pendapatan. 


\section{A. Pendahuluan}

Kemiskinan merupakan masalah dalam pembangunan yang bersifat multidimensi karena dalam menanggulanginya masalah yang dihadapi bukan saja tebatas pada hal-hal yang menyangkut hubungan sebab akibat timbulnya kemiskinan tetapi melibatkan juga preferensi, nilai dan politik (Ali Khomsan,2015:1). Kemiskinan juga merupakan sebuah permasalahan ekonomi yang harus dicarikan jalan keluarnya. Masyarakat yang dikategorikan miskin salah satunya berkaitan dengan rendahnya pendapatan yang diperoleh dalam memenuhi kebutuhan hidupnya seharihari.Kemiskinan akan menjadi ancaman serius dimasa mendatang ketika hal tersebut dibiarkan dan tidak mendapat perhatian khusus dari pemerintah (Garry, 2011).

Salah satu cara menanggulangi kemiskinan adalah dukungan orang yang mampu untuk mengeluarkan harta kekayaan mereka berupa dana zakat kepada mereka yang kekurangan. Sebagaimana yang tercantum dalam alQur'an, yang artinya:

ambillah zakat dari sebagian harta mereka, dengan zakat itu kamu membersihkandan mensucikan mereka dan mendoalah untuk mereka. Sesungguhnya doa kamu itu (menjadi) ketenteraman jiwa bagi mereka. dan Allah Maha mendengar lagi Maha mengetahui (Depag, RI).

Zakat merupakan salah satu pendekatan Islam dalam pengentasan kemiskinan dan pencapaian pemerataan kesejahteraan, solusi yang mampu mengurangi beban hidup bagi orang yang tidak mampu (fakir miskin) dan menjadi bagian ibadah bagi orang yang mampu (Adi Sasono,1998:79). Selain itu zakat juga merupakan salah satu dari lima nilai instrumental yang strategis dan sangat berpengaruh pada tingkah laku ekonomi manusia dan masyarakat serta pembangunan ekonomi umumnya.Tujuan zakat tidak sekedar menyantuni orang miskin secara konsumtif, tetapi mempunyai tujuan yang lebih permanen yaitu mengentaskan kemiskinan (Mila Sartika). Dengan demikian pengelolaan dana zakat dalam rangka pengembangan ekonomi umat, perlu diarahkan sebagai sarana pemerataan kemakmuran rakyat dan pemecahan masalah kemiskinan umat. Dengan pendayagunaan dana zakat sebagai sarana pemecahan problema kemiskinan umat Islam itu, maka adanya penyempitan dan kesenjangan kesejahteraan umat akan terwujud dengan baik.

Pola penyaluran zakat seiring dengan perkembangan zaman terus mengalami perkembangan. Pada saat ini telah muncul konsep penyaluran zakat dalam bentuk bantuan permodalan usaha bagi pihak yang berhak menerima zakat yang memiliki usaha atau yang masih mampu melakukan suatu usaha dalam hal ini penerima tersebut harus memiliki keahlian dalam berwirausaha agar usaha yang dijalankannya tersebut dapat berkembang dan berjalan dengan lancar sehingga penghasilanya dapat meningkat. Beda halnya dengan zakat konsumtif yang hanya menolong fakir miskin dalam jangka pendek, mereka bisa saja terlepas dari kemiskinan material tetapi sesaat, serta tetap tidak bisa terlepas dari kemiskinan struktural (Adel, 2016).

Dengan berkembangnya sistem pengelolaaan dan pemberdayaan zakat, Badan Amil Zakat sudah mencapai tingkat kabupaten dan kota. Badan Amil Zakat adalah organisasi pengelola zakat yang dimiliki pemerintah berdasarkan UU No 38 Tahun 1999 yang 
diperbaharui dengan UU No 23 Tahun 2011 tentang pengelolaan zakat. UU tersebut menentukan bahwa pemerintah berperan secara langsung dalam pengelolaan zakat dengan membentuk Badan Amil Zakat dari tingkat pusat sampai tigkat daerah. Seperti di Provinsi Gorontalo beberapa Baznas atau LAZ sukses dan berkembang pada pelaksanaanya, salah satunya Baznas Kota Gorontalo. Baznas Kota Gorontalo merupakan lembaga yang dijadikan sebagai salah satu sarana untuk pemberdayaan ekonomi bagi masyarakat miskin. Baznas tersebut mengeluarkan beberapa program yang salah satunya zakat produktif.

Zakat produktif merupakan pemberian santunan kepada masyarakat miskin untuk mengembangkan usahausaha produktif dalam rangka meningkatkan pendapatan mustahik (Moh. Thoriquddin, 2015:29). Dengan adanya zakat tersebut, fakir miskin akan mendapatkan penghasilan tetap, meningkatkan usaha, serta dapat mengembangkan usaha. Program bantuan modal usaha yang di berikan kepada orang miskin, dengan tujuan agar mereka dapat meningkatkan kehidupan yang semestinya. Selain itu, tingkat pendapatan mustahik sebelum dan sesudah menerima zakat produktif terdapat perbedaan, dimana perbedaan tersebut rata-rata mengalami peningkatan walaupun dalam jumlah yang relatif sedikit. Adapun pendapatan mustahik sebelum menerima bantuan rata-rata perbulan berjumlah sebesar Rp. 2.700.000, setelah menerima bantuan dari Baznas penghasilan mereka meningkat rata-rata berjumlah sebesar Rp 4.500.000 perbulan. Karena dalam penyaluran bantuan zakat produktif lembaga baznas hanya mengadakan sosialisasi, akan tetapi tidak disertai pelatihan khusus untuk bagaimana mengelola dana zakat yang telah disalurkan.

Program kebijakan Baznas yang berbasis pemberdayaan masyarakat bertujuan untuk meningkatkan kesejahteraan masyarakat miskin. Program bantuan modal usaha kecil (mikro) yang di salurkan oleh Baznas Kota Gorontalo merupakan salah satu pengentasan kemiskinan. Adapun penyaluran zakat produktif penerimanya berjumlah 250 orang dengan bantuan sejumlah Rp 500.000 dalam bentuk bahan pokok serta uang tunai sebesar 100 ribu/ orang yang di salurkan pada tahun 2015 di 50 kelurahan di Kota Gorontalo (Azmi Yasin Baznas Kota Gorontalo). Kondisi inilah yang menarik perhatian penulis untuk meneliti variabel yang mempengaruhi pendapatan masyarakat dengan mengambil judul "Pengaruh Zakat Produktif dan Minat Berwirausaha Terhadap Peningkatan Pendapatan Masyarakat Miskin Pada Baznas Kota Gorontalo"

\section{B. Landasan Teori}

\section{Zakat}

Zakat merupakan rukun Islam ketiga. Secara harfiah (etimologi) kata "zakat" berarti tumbuh, berkembang, mensucikan, atau membersihkan. Sedangkan secara istilah (terminologi) kata zakat merujuk pada aktivitas memberikan sebagian harta kekayaan dalam jumlah tertentu untuk diberikan kepada golongan tertentu (JESTT Vol. 1). Dengan demikian zakat yang dikeluarkan akan mensucikan diri dari dosa dan menyuburkan harta atau memperbanyak pahala bagi orang yang mau mengeluarkan zakat tersebut. Dasar hukum zakat adalah:

a. Al-Qur'an 
Pentingnya zakat secara mendasar terdapat dalam Qs. Albaqarah: 277 yang berbunyi:

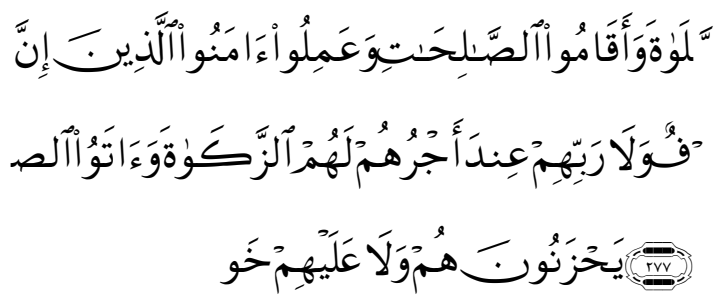

Terjemahannya:

Sesungguhnya orang-orang yang beriman, mengerjakan amal saleh, mendirikan shalat dan menunaikan zakat, mereka mendapat pahala di sisi Tuhannya. tidak ada kekhawatiran terhadap mereka dan tidak (pula) mereka bersedih hati.

b. Hadits

Diriwayatkan oleh Bukhari Muslim dari Abu Hurairah ra, Rasulullah SAW bersabda:

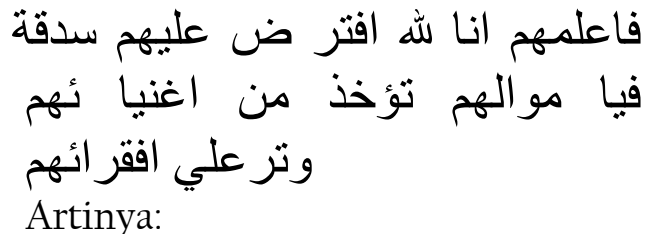

beritahukanlah kepada mereka bahwa Allah mewajibkan pemungutan zakat dari orangorang yang berada dikalangan mereka untuk diberikan kepada orang-orang miskin dari kalangan mereka juga (Abi Abdillah:430).

Dari dalil diatas dapat disimpulkan bahwa kita sebagai umat muslim diwajibkan untuk mengeluarkan sebagian harta, untuk diberikan kepada orang-orang yang kurang mampu agar bisa mengangkat derajat mereka dan membantunya keluar dari kesulitan hidup serta penderitaan.

Mengenai penerima zakat, yang berhak menerima zakat menurut UU
No. 38 Tahun 1999 tentang pengelolaan zakat dan menurut ketentuan al-Qur'an surah At-Taubah ayat 60 adalah:

a) Fakir, yaitu orang yang tidak berharta dan tidak pula mempunyai pekerjaan atau usaha tetap guna mencukupi kebutuhan hidupnya (nafkah), sedang orang yang menaggungnya (menjamin hidupnya) tidak ada.

b) Miskin, yaitu orang-orang yang tidak dapat mencukupi kebutuhan hidupnya, meskipun ia mempunyai pekerjaan atau usaha tetap, tetapi hasil usahanya itu belum mencukupi kebutuhannya dan orang yang menanggungnya tidak ada.

c) Amil, yaitu panitia atau organisasi yang melaksanakan segala kegiatan urusan zakat, baik mengumpulkan, membagikan maupun mengelolanya. Allah SWT menydiakan upah bagi amilin dari harta zakat sebagai imbalan.

d) Muallaf, yaitu orang yang masih lemah imannya karna baru memeluk agama Islam atau orang yang ada keinginan untuk masuk tetapi masih ragu-ragu. Dengan bagian zakat, dpat memantapkan hatinya di dalam Islam.

e) Riqab, yaitu hamba sahaya yang perlu diberikan bagian zakat agar mereka dapat melepaskan diri dari belenggu perbudakan.

f) Gharimin, yaitu orang yang punya hutang karena sesuatu kepentingan yang bukan untuk perbuatan maksiat dan ia tidak mampu untuk membayar atau melunasinya.

g) Sabilillah, yaitu usaha-usaha yang tujuannya untuk meningkatkan atau meninggikan syiar Islam seperti membela atau mempertahankan agama, 
mendirikn tempat ibadah, rumah sakit dan lain-lain.

h) Ibnussabil, yaitu orang yang kehabisan bekal dalam perjalanan dengan maksud baik atau musafir yang memerlukan bantuan (Hasan, 1995:43).

Salah satu fungsi zakat adalah fungsi sosial, yaitu sarana bersosialisasi antara orang kaya dan miskin. Dalam distribusi zakat terdapat dua model distribusi yaitu konsumtif dan produktif. Kedua model tersebut masing-masing terbagi menjadi dua yaitu konsumtif tradisional dan konsumtif kreatif, serta produktif konvensional dan produktif kreatif.

a. Konsumtif tradisional, yaitu zakat dibagikan kepada mustahik secara langsung untuk konsumsi seharihari, seperti pembagian zakat mal maupun zakat fitrah kepada mustahik yang sangat membutuhkan karena ketiadaan pangan atau karena musibah. Program ini merupakan program jangka pendek dalam mengatasi permasalahan umat.

b. Konsumtif kreatif, yaitu dana zakat merupakan barang konsumtif dan digunakan membantu orang miskin dalam mengatasi permasalahan sosial ekonomi yang dihadapinya. Bantuan tersebut seperti alat-alat sekolah, dan beasiswa untuk pelajar, bantuan sarana ibadah seperti sarung dan mukena dan lain-lain.

c. Produktif konvensional, yaitu dana zakat diberikan dalam bentuk barang-barang produktif. Dengan pemberian tersebut mustahik bisa menciptakan lapangan pekerjaan sendiri, seperti pemberian bantuan ternak kambing, sapi perah atau untuk membajak sawah, mesin jahit dan sebagainya.

d. Produktif kreatif, yaitu zakat diberikan dalam bentuk pemberian modal bergulir, seperti pembangunan sekolah, saran kesehatan atau tempat ibadah, maupun sebagai modal usaha bagi pengembangan usaha pedagang kecil. ( Thoriquddin, 34).

Zakat produktif merupakan model pendistribusian zakat yang dapat membuat para mustahik menghasilkan sesuatu secara terus menerus, dengan harta zakat yang diterimanya. Menurut Isnaini bahwa zakat produktif adalah harta zakat yang diberikan kepada mustahik tidak dihabiskan atau dikonsumsi tetapi dikembangkan dan digunakan untuk membantu usaha mereka, sehingga dengan usaha tersebut mustahik dapat memenuhi kebutuhan hidup secara terus menerus. Selain itu, Qadir juga mengemukakan bahwa zakat produktif yaitu zakat yang diberikan kepada mustahik sebagai modal untuk menjalankan suatu kegiatan ekonomi yaitu menumbuh kembangkan tingkat ekonomi dan potensi produktifitas mustahik (Qadir, 2001:165). Dengan demikian zakat produktif adalah dana zakat yang diberikan kepada para mustahik tidak dihabiskan akan tetapi dikembangkan dan digunakan untuk membantu usaha mereka.

Pengelolaan zakat dalam islam merupakan aktivitas pengelolaan zakat yang telah diajarkan oleh Islam dan telah dipraktekkan oleh Rasulullah Saw. Dan penerusnya yaitu para sahabat. Selain itu, di Indonesia juga pengelolaan zakat sudah diatur dalam UU No. 38 Tahun 1999 tentang pengelolaan zakat pasal 5 yang sudah direvisi dengan UU zakat yang disyahkan pada tanggal 27 oktober 
Tahun 201l. Dalam UU tersebut mendorong upaya pembentukan lembaga pengelola zakat yang amanah kuat dan dipercaya oleh masyarakat.

Terdapat beberapa keuntungan dari pengelolaan zakat yang dilakukan oleh lembaga pengelola zakat dan yang memiliki kekuatan hukum formal antara lain: Pertama, untuk menjamin kepastian dan kedisiplinan pembayar zakat. Kedua, untuk menjaga perasaan rendah diri para mustahik zakat apabila berhadapan langsung untuk menerima zakat dari para muzakki. Ketiga, untuk mencapai efisiensi efektifitas, serta sasaran yang tepat dalam penggunaan harta zakat menurut skala prioritas yang ada pada suatu tempat. Keempat, untuk memperlihatkan syi'ar Islam dalam semangat penyelenggaraan pemerintahan yang Islami (Thoriquddin, 2015:42).

Pola pendistribusian zakat produktif haruslah diatur sedemikian rupa sehingga jangan sampai sasaran dari program ini tidak tercapai. Menurut Armiadi terdapat beberapa langkah yang menjadi acuan dalam pendistribusian zakat produktif diantaranya adalah:

(a) Forecasting yaitu meramalkan, memproyeksikan dan mengadakan taksiran sebelum pemberian zakat.

(b) Planning yaitu merumuskan dan merencanakan suatu tindakan tentang apa saja yang akan dilaksanakan untuk tercapainya program, seperti penentuan orang-orang yang akan mendapat zakat produktif, menentukan tujuan yang ingin dicapai, dan lain-lain.

(c) Organizing dan Leading yaitu mengumpulkan berbagai elemen yang akan membawa kesuksesan program termasuk di dalamnya membuat peraturan yang baku yang harus ditaati.

(d) Controlling yaitu pengawasan terhadap jalannya program sehingga jika ada sesuatu yang tidak beres atau menyimpang dari prosedur akan segera terdeteksi (Armiadi, 2008:69).

Masjfuk Zuhdi menyebutkan bahwa seleksi bagi para penerima zakat produktif haruslah dilakukan secara ketat, sebab banyak orang fakir miskin yang masih jasmani dan rohaninya tetapi mereka malas bekerja. Mereka lebih suka jadi gelandangan daripada menjadi buruh atau karyawan. Mereka itu tidak boleh diberi zakat, tetapi cukup diberi sedekah ala kadarnya, karena mereka merusak citra Islam. Karena itu fakir miskin itu harus diseleksi lebih dahulu, kemudian diberi pelatihan keterampilan yang sesuai dengan bakatnya, kemudian baru diberi modal kerja yang memadai (Nasrullah, 2015).

\section{Minat Berwirausaha}

Minat merupakan keadaan psikis yang timbul dari dalam diri seseorang dimana cenderung lebih suka dan lebih tertarik oleh suatu objek, serta menginginkan objek tersebut tanpa adanya keterpaksaan. Minat menimbulkan keinginan untuk mengetahui dan mempelajari suatu objek tertentu dengan perasaan senang dan berniat untuk mewujudkannya sebagai pilihan hidup (Adhe, 2016). Menurut Winkel minat yaitu kecenderungan yang menetap pada seseorang untuk merasa tertarik pada suatu bidang tertentu dan merasa senang dalam berbagai kegiatan yang berkaitan dengan bidang itu sendiri (Winkel, 2004:650). Menurut Purwanto minat adalah perbuatan yang berpusat kepada suatu tujuan dan merupakan 
suatu dorongan bagi perbuatan itu sendiri (Ngalim, 2006:56).

Minat untuk berwirausaha dapat diukur melalui 3 (tiga) macam indikator yaitu sebagai berikut (Slameto, 2010:182):

1) Kognisi, yang meliputi: pengetahuan kewirausahaan terhadap minat berwirausaha.

2) Emosi, yang meliputi: perasaan senang, ketertarikan dan perhatian terhadap minat berwirausaha.

3) Konasi, yang meliputi: keinginan, usaha dan keyakinan terhadap minat berwirausaha.

Karasteristik dan perilaku yang mendukung pada diri seorang wirausahawan. Karasteristik dan perilaku sangat dipengaruhi oleh sifat dan watak yang dimiliki oleh seseorang. Adapun karasteristik dan perilku wirausaha terdiri dari (Slameto, 2010:64):

1. Percaya diri: yang indiktornya adalah keyakinan, kemandirian, individualitas, optimisme.

2. Berorientasikan tugas dan hasil: yang indikatornya adalah kebutuhan akan prestasi, berorientasi pada laba, memiliki ketekunan dan ketabahan, memiliki tekad yang kuat, suka bekerja keras, energik dan memiliki inisiatif.

3. Pengambil risiko: yang indikatornya memiliki kemampuan mengambil risiko dan suka pada tantangan.

4. Kepemimpinan: yang indikatornya adalah bertingkah laku sebagai pemimpin, dapat bergaul dengan orang lain dan suka terhadap saran dan kritik yang membangun.
5. Keorisinilan: yang indikatornya adalah memiliki inovasi dan kreativitas tinggi, fleksibel, serba bisa dan memiliki jaringan bisnis yang luas.

6. Berorientasi ke masa depan: yang indikatornya memiliki persepsi dan cara pandang (orientasi) pada masa depan.

7. Jujur dan tekun: yang indikatornya memiliki keyakinan bahwa hidup itu sama dengan kerja. Dalam skala makro, kehadiran para wirausahawan diharapkan dapat meningkatkan pertumbuhan ekonomi yang pada gilirannya dapat menyerap tenaga kerja baru. Daya serap pertumbuhan ekonomi Indonesia diharapkan meningkatkan dua kali lipat agar jumlah lapangan kerja baru yang tersedia bertambah dan angkatan kerja baru mendapatkan pekerjaan. Hal ini diperlukan karena pertumbuhan ekonomi yang ada sekarang belum mampu menyediakan lapangan kerja baru bagi para penganggur.

Berwirausaha tidak selalu memberikan hasil yang sesuai dengan harapan dan keinginan pengusaha. Tidak sedikit pengusaha yang mengalami kerugian dan akhirnya bangkrut. Namun, banyak juga wirausahawan yang berhasil untuk beberapa generasi. Bahkan, banyak pengusaha yang semula hidup sederhana menjadi sukses dengan ketekunannya. Keberhasilan atas usaha yang dijalankan memang merupakan harapan pengusaha. Adapun ciri-ciri wirausahawan yag dikatakan berhasil yaitu sebagai berikut:

a. Memiliki visi dan tujuan yang jelas. Hal ini berfungsi untuk menebak kemana langkah dan arah yang dituju, sehingga dapat 
diketahui apa yang akan dilakukan oleh pengusaha tersebut.

b. Inisiatif dan selalu proaktif. Ini merupakan ciri mendasar dimana pengusaha tidak hanya menunggu sesuatu terjadi, tetapi terlebih ahulu memulai dan mencari peluang sebagai pelopor dalam berbagai kegiatan.

c. Berorientasi pada prestasi. Pengusaha yang sukses selalu mengejar prestasi yang lebih baik daripada prestasi sebelumnya. Mutu produk, pelayanan yang diberikan, serta kepuasan pelanggan yang menjadi perhatian utama.

d. Berani mengambil risiko. Hal ini merupakan sifat yang harus dimiliki seorang pengusaha kapanpun dan dimanapun, baik dalam bentuk uang maupun waktu.

e. Kerja keras. Kadang-kadang seorang pengusaha sulit untuk mengatur waktu kerjanya. Benaknya selalu memikirkan kemajuan usahanya. Ide-ide baru selalu mendorongnya untuk bekerja keras merealisasikannya.

f. Mengembangkan dan memelihara hubungan baik dengan berbagai pihak, baik yang berhubungan langsung dengan usaha yang dijalankan mupun tidak. Hubungan baik yang perlu dijalankan antara lain kepada pelanggan, pemerintah, pemasok, serta masyarakat luas.

Menurut Zimmerer ada beberapa faktor yang menyebabkan wirausaha gagal dalam menjalankan usaha barunya ((Slameto, 2010:40):

a. Tidak kompeten dalam manajerial. b. Kurang berpengalaman baik dalam kemampuan mengkoordinasikan,

keterampilan mengelola sumber daya manusia, maupun kemampuan mengintegrasikan operasi perusahaan.

c. Kurang dapat mengendalikan keuangan.

d. Gagal dalam perencanaan.

e. Lokasi yang kurang memadai.

f. kurangnya pengawasan peralatan.

g. Sikap yang kurang sungguhsungguh dalam berusaha.

\section{Pendapatan}

Pendapatan Menurut Sukirno adalah jumlah penghasilan yang diterima oleh penduduk atas prestasi kerjanya selama satu periode tertentu, baik harian, mingguan, bulanan ataupun tahunan (Sadono, 2004:84). Definisi pendapatan menurut ilmu ekonomi menutup kemungkinan perubahan lebih dari total harta kekayaan badan usaha pada awal periode, dan menekankan pada jumlah nilai statis pada akhir periode. Secara garis besar pendapatan adalah jumlah harta kekayaan awal periode ditambah perubahan penilaian yang bukan diakibatkn perubahan modal dan hutang (Yulin Hango. 2012).

Pendapatan atau income masyarakat adalah hasil penjualan dari faktor-faktor produksi yang dimilikinya pada sektor produksi dan sektor ini membeli faktor-faktor produksi tersebut untuk digunakan sebagai input prosesproses produksi dengan harga yang berlaku dipasar faktor produksi. Harga pasar ditentukan oleh tarik menarik antara penawaran dan permintaan (Karim. 2012).

Pendapatan bagi pihak business diperoleh dari pembelian yang dilakukan oleh masyarakat untuk 
memperoleh barang dan jasa yang dihasilkan atau diproduksi oleh pihak business. Menurut Milton Friedman teori pendapatan masyarakat dapat diklasifikasikan menjadi 2 yaitu (Friedman, 2008:19):

a. Pendapatan permanen (permanent income), yaitu pendapatan yang orang harapkan untuk terus bertahan di masa depan

b. Pendapatan sementara (transitory income), ialah pendapatan yang tidak bisa diperkirakan sebelumnya.

Besar kecilnya tingkat pendapatan yang diterima seseorang tergantung pada apakah orang lain memanfaatkan sumber-sumber yang dimilikinya dalam menghasilkan barang yang sangat diinginkan konsumen atau tidak, disamping itu juga tegantung pada sumber-sumber perekonomian. Artinya pertama, pendapatan atau penghasilan yang rendah disebabkan karena sedikitnya sumber-sumber yang dimiliki atau karena menempatkan penggunaan sumber-sumber untuk menghasilkan barang yang memberikan sedikit kepuasan pada konsumen. Kedua, pendapatan atau penghasilan yang tinggi disebabkan banyaknya sumbersumber yang dimiliki atau karena menggunakan sumber-sumber yang

\begin{tabular}{|l|l|l|l|}
\hline Variabel & Definisi & Indikator & Skala \\
\hline \multirow{3}{*}{ Zakat Produktif } & Zakat produktif yaitu & a. Forcasting & \\
$\left(\mathrm{X}_{1}\right)$ & penyaluran dana zakat yang & b. Planning & \\
& dilakukan oleh lembaga & c. Oranizing & Likert \\
& LAZ/BAZ untuk & d. Controlling & \\
& masyarakat miskin dalam & & \\
& bentuk modal usaha untuk & & \\
& meningkatkan pendapatan & & \\
& mereka dan bisa merubah & & \\
& status mereka dari & & \\
\hline \multirow{3}{*}{ Minat } & Keinginan menjadi muzakki & & \\
& kesungguhan yang timbul & b. Emosi, & \\
\hline
\end{tabular}

dimiliki untuk menghasilkan barang yang banyak memberi kepuasan pada konsumen (Richard, 1984:33).

Adapun faktor-faktor yang mempengaruhi pendapatan menurut Bintari dan Suprihatin adalah sebagai berikut (Yulin, 2012):

a. Kesempatan kerja yang tersedia

b. Kecakapan dan keahlian

c. Motivasi

d. Keuletan bekerja

e. Banyak sedikitnya modal yang digunakan

\section{Metode Penelitian}

Dalam penelitian ini, penulis menggunakan metode kuantitaif yaitu peneliti ingin menjelaskan hubungan pengaruh dan perbedaan antara variabel $X_{1}$ (Zakat Produktif), $X_{2}$ (minat berwirausaha) dan variabel $\mathrm{Y}$ (Pendapatan masyarakat miskin) pada baznas di kota Gorontalo. Populasi dalam penelitian ini sebanyak 250 penerima zakat produktif dan adapun sampel adalah 71 sampel. Metode pengambilan sampel secara random sampling. Sumber data dalam penelitian ini adalah data primer dan data sekunder. Adapun tabel dibawah ini menggambarkan penjabaran dalam konsep dan indikator-indikator, yaitu: 


\begin{tabular}{|l|l|l|l|}
\hline $\begin{array}{l}\text { Berwirausaha } \\
\left(\mathrm{X}_{2}\right)\end{array}$ & $\begin{array}{l}\text { pada diri sesorang dalam } \\
\text { mendirikan atau mengelola } \\
\text { suatu usaha secara kreatif, } \\
\text { sehingga bisa mencapai } \\
\text { hasil yang maksimal }\end{array}$ & Likert \\
\hline $\begin{array}{l}\text { Pendapatan } \\
\text { Masyarakat }\end{array}$ & $\begin{array}{l}\text { Penghasilan yang diperoleh } \\
\text { atas kerja keras seseorang } \\
\text { baik dalam bentuk uang } \\
\text { (Y) }\end{array}$ & $\begin{array}{l}\text { a. pendapatan } \\
\text { permanen } \\
\text { memenuhi barang untuk } \\
\text { hidupnya kebutuhan } \\
\text { bementara }\end{array}$ & Likert \\
& & & \\
\hline
\end{tabular}

Teknik analisis data yang digunakan dalam penelitian ini adalah analisis regresi berganda, namun terlebih dahulu dilakukan uji validitas, uji reliabilitas dan uji normalitas data. Sedangkan untuk menghitung pengaruh secara kuantitatif dari suatu perubahan kejadian (variabel $X$ ) terhadap kejadian lainnya (variabel Y). Dalam penelitian ini, analisa regresi berganda berperan sebagai teknik statistik yang digunakan untuk menguji ada tidaknya pengaruh Zakat Produktif, minat berwirausaha terhadap Pendapatan masyarakat miskin pada Baznas kota Gorontalo.

Analisis regresi menggunakan rumus persamaan regresi berganda yaitu sebagai berikut:

Dimana :

$$
Y=a+b_{1} X_{1}+b_{2} X_{2}+e
$$

$\mathrm{Y}=$ Pendapatan masyarakat miskin pada zakat produktif Baznas Kota Gorontalo

$\mathrm{X}_{\mathrm{l}}=$ Zakat Produktif

$\mathrm{X}_{2}=$ minat berwirausaha

$\mathrm{a}=$ Nilai Konstanta

$\mathrm{b}_{1}, \mathrm{~b}_{2}=$ Koefisien Regresi

e = Kesalahan observasi atau pengganggu

(merupakan bentuk variabel lainnya yang tidak diteliti oleh peneliti.

Teknik analisa yang digunakan sesuai model di atas adalah regresi berganda dimana nilai dari variabel dependen (Pendapatan masyarakat miskin) dapat diperoleh dari hasil survey yang digunakan skala Likert. (Sugiyono, 2008:92). Untuk mencari besarnya hubungan dan kontribusi variabel pengaruh $\mathrm{X}_{\mathrm{l}}$ (Zakat Produktif), $\mathrm{X}_{2} \quad$ (minat berwirausaha) secara bersama-sama dengan variabel Y ( Pendapatan masyarakat miskin).

\section{Hasil Penelitian}

\section{Deskripsi Data}

Analisis deskriptif digunakan untuk mengetahui hasil tanggapan responden terhadap variabel-variabel yang digunakan melalui item kuisioner yang diajukan. Selanjutnya untuk pengelolaan distribusi frekuensi dari masing-masing variabel tersebut dilakukan dengan mengelompokkan skor nilai dari jawaban responden penelitian. Distribusi frekuensi hasil jawaban responden merupakan tingkat kecendrungan persepsi terhadap variabel-variabel yang ada diantaranya adalah variabel $X_{1}$ (Zakat Produktif), $\mathrm{X}_{2}$ (minat berwirausaha) dan $\mathrm{Y}$ ( 
Pendapatan masyarakat miskin). Berikut ini akan ditentukan dahulu range skor yang akan dijadikan sebagai perbandingan hasil dari jawaban responden.

\section{Uji Persyaratan Analisis}

a. Uji Validitas

Uji validitas di gunakan untuk mengetahui tingkat kecermatan suatu alat ukur dalam menjalankan fungsi ukurnya. Uji Validitas digunakan dengan menggunakan perhitungan product moment terhadap semua item kuesioner. Jumlah responden adalah sebanyak 71 orang. Dasar pertimbangan untuk mengetahui valid tidaknya kuesioner adalah dengan melihat rhitung. Item kuesioner dikatakan valid jika $r_{\text {hitung }}>$ dari $r_{\text {tabel.Nilai }} r_{\text {tabel }}$ pada $\alpha=10 \%$ atau 0,1 yaitu 0,1968

Ada dua variabel independen dan satu variabel dependen yang digunakan dalam penelitian ini yaitu :

\begin{tabular}{|c|c|c|c|c|}
\hline Variabel & No Insrumen & $\mathrm{R}_{\text {hitung }}$ & $\overline{\mathrm{R}_{\text {tabel }}}$ & Keterangan \\
\hline \multirow{5}{*}{$\begin{array}{l}\text { Zakat Produktif } \\
\text { (xl) }\end{array}$} & 1 & 0,577 & 0,196 & Valid \\
\hline & 2 & 0,430 & 0,196 & Valid \\
\hline & 3 & 0,447 & 0,196 & Valid \\
\hline & 4 & 0,590 & 0,196 & Valid \\
\hline & 5 & 0,462 & 0,196 & Valid \\
\hline \multirow{6}{*}{$\begin{array}{l}\text { Minat } \\
\text { Berwirausaha } \\
\text { (xl) }\end{array}$} & 6 & 0,398 & 0,196 & Valid \\
\hline & 7 & 0,474 & 0,196 & Valid \\
\hline & 8 & 0,412 & 0,196 & Valid \\
\hline & 9 & 0,514 & 0,196 & Valid \\
\hline & 10 & 0,529 & 0,196 & Valid \\
\hline & 11 & 0,538 & 0,196 & Valid \\
\hline \multirow{5}{*}{$\begin{array}{l}\text { Peningkatan } \\
\text { Pendapatan } \\
\text { Masyarakat } \\
\text { Miskin (Y) }\end{array}$} & 12 & 0,463 & 0,196 & Valid \\
\hline & 13 & 0,365 & 0,196 & Valid \\
\hline & 14 & 0,386 & 0,196 & Valid \\
\hline & 15 & 0,556 & 0,196 & Valid \\
\hline & 16 & 0,485 & 0,196 & Valid \\
\hline
\end{tabular}




\begin{tabular}{|l|l|l|l|l|}
\hline 17 & 0,539 & 0,196 & Valid \\
\cline { 2 - 5 } & 18 & 0,578 & 0,196 & Valid \\
\hline
\end{tabular}

Berdasarkan tabel di atas menunjukkan bahwa semua butir pertanyaan dari masing-masing variabel Zakat Produktif (Xl), Minat Berwirausaha (X2) dan Peningkatan Pendapatan Masyarakat Miskin (Y) adalah valid karena menunjukkan hasil $\mathrm{r}_{\text {hitunglebih besar dari } \mathrm{r}_{\text {tabel, }} \text { artinya semua }}$ butir pertanyaan dapat digunakan instrumen penelitian.

b. Uji Reliabilitas

Merupakan alat untuk mengukur suatu kuesoner yang merupakan indikator dan variabel. Suatu kuesioner dikatakan reliabel jika jawaban seseorang terhadap pertanyaan pertanyaan konsisten atau stabil dari waktu ke waktu. SPSS memberikan fasilitas untuk mengukur realibilitas dengan uji statistik Cronboac Alpha $(\alpha)$. Suatu variabel dikatakan reliabel jika memberikan nilai $\alpha>0.60$. Hasil uji realibilitas masing-masing variabel adalah sebagai berikut.

\begin{tabular}{|l|l|l|}
\hline Variabel & Koefisien Realibilitas & Keterangan \\
\hline Zakat Produktif $(\mathrm{Xl})$ & 0,645 & Reliabel \\
\hline $\begin{array}{l}\text { Minat Berwirausaha } \\
(\mathrm{x} 2)\end{array}$ & 0,663 & Reliabel \\
\hline $\begin{array}{l}\text { Peningkatan } \\
\text { Pendapatan } \\
\text { Masyarakat } \\
\text { Miskin(Y) }\end{array}$ & 0,679 & Reliabel \\
\hline
\end{tabular}

Berdasarkan tabel diatas menunjukkan bahwa diperoleh nilai dari masing-masing variabel dapat dikatakan reliabel, karena hasil dari nilai koefisien realibilitas lebih dari 0,60. Artinya semua butir dari masingmasing variabel bisa dijadikan sebagai instrumen penelitian. c. Uji Normalitas

Uji normalitas digunakan untuk menguji apakah model regresi memenuhi asumsi normalitas. Untuk mengujinya digunakan normal probability plot. Dari normal probability plot. Terlihat bahwa titik-titk data membentuk pola linier sehingga dengan distribusi normal. 


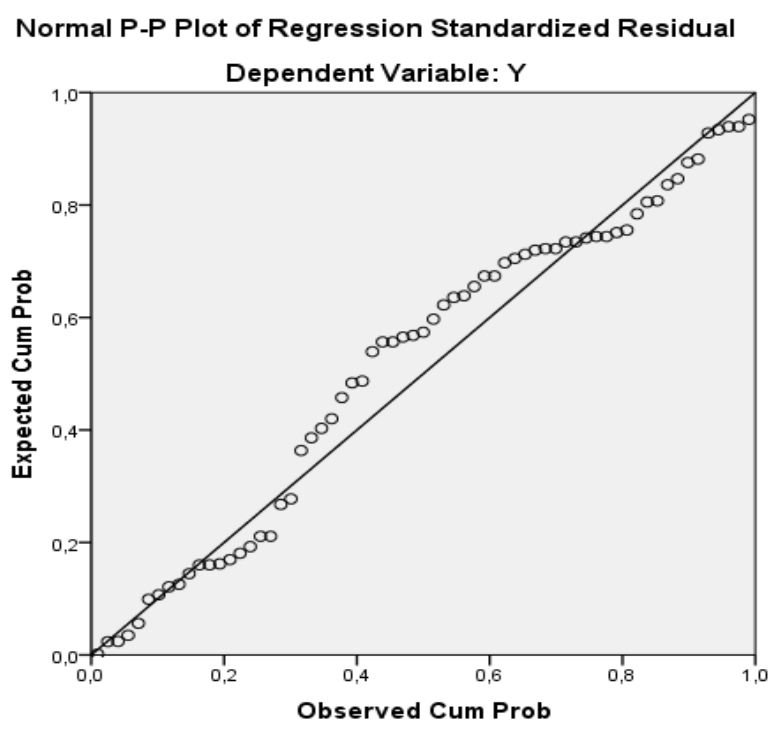

Berdasarkan Grafik 4.3. di atas menunjukkan bahwa pengujian normalitas berdistribusi normal. Hal ini dapat dilihat bahwa garis yang menggambarkan data sesungguhnya mengikuti garis diagonal. Artinya bahwa sebaran data dikatakan tersebar disekeliling gari lurus (tidak terpancar jauh dari garis lurus), sehingga persyaratan normalitas bisa dipenuhi.

\section{E. Analisis hasil Penelitian}

Sebelum dilakukan analisa terhadap data yang diperoleh maka sebelumnya data harus memenuhi persyaratan analisa. Analisa regresi dipersyaratkan data harus terditribusi normal dan linear, dengan demikian berdasarkan uji asumsi klasik, maka data tersebut layak untuk dianalisis dan semua memenuhi persyaratan kriteria analisis.

\section{Analisis Regresi Berganda}

Analisis data dan pengujian dalam penelitian ini akan dilakukan dengan menggunakan model regresi linier berganda untuk mengetahui pengaruh Zakat Produktif (Xl) dan Minat Berwirausaha (X2) terhadap Peningkatan Pendapatan Masyarakat Miskin (Y). Di mana pengolahan data menggunakan bantuan SPSS 21.

Berikut ini adalah hasil output dari regresi bergnda dapat dilihat pada tabel berikut:

\section{Coefficients}

\begin{tabular}{|c|c|c|c|c|c|}
\hline \multirow[t]{2}{*}{ Model } & \multicolumn{2}{|c|}{$\begin{array}{l}\text { Unstandardized } \\
\text { Coefficients }\end{array}$} & \multirow{2}{*}{\begin{tabular}{|l|}
$\begin{array}{l}\text { Standardized } \\
\text { Coefficients }\end{array}$ \\
Beta
\end{tabular}} & \multirow[t]{2}{*}{$t$} & \multirow[t]{2}{*}{ Sig. } \\
\hline & $B$ & Std. Error & & & \\
\hline (Constant) & 7,868 & 3,769 & & 2,087 &, 041 \\
\hline $\begin{array}{l}\text { Zakat } \\
\text { produktif }\end{array}$ &, 636 & , 148 &, 430 & 4,310 &, 000 \\
\hline $\begin{array}{l}\text { Minat } \\
\text { Bewirausah } \\
\text { a }\end{array}$ &, 329 &, 098 &, 334 & 3,352 &, 001 \\
\hline
\end{tabular}

a. Dependent Variable: Pendapatan Masyarakat Miskin 


\section{Uji Koefisien Determinasi}

Dari hasil pengujian koefisien determinasi yang telah dilakukan terhadap data yang ada, maka diperoleh sebagai berikut:

\begin{tabular}{|l|l|l|l|l|}
\hline $\begin{array}{l}\text { Mode } \\
1\end{array}$ & $R$ & R Square & $\begin{array}{l}\text { Adjusted } \\
\text { Square }\end{array}$ & $\begin{array}{l}\text { Std. Error of } \\
\text { the Estimate }\end{array}$ \\
\hline 1 &, $584^{\mathrm{a}}$ &, 341 &, 322 & 2,185 \\
\hline
\end{tabular}

A. Predictors: (Constant), Minat Berwirausaha, Zakat Produktif

B. Dependent Variable: Pendapatan Masyarakat Miskin

ANOVA $^{\mathrm{a}}$

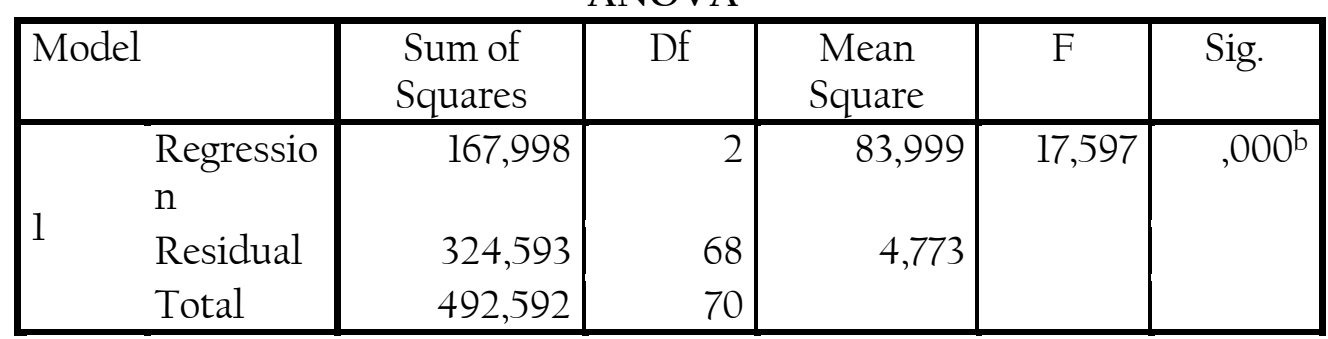

a. Dependent Variable: Pendapatan Masyarakat

b. Predictors: (Constant), Spirit Kewirausahaan, Zakat Produktif

Beberapa kesimpulan yang dapat Diambil dari tabel di atas adalah:

a. Variabel zakat produktif (XI) peningkatan pendapatan masyarakat $(\mathrm{Y})$, diperoleh nilai sig 0,000 lebih kecil dari nilai probabilitas 0,05 atau $0,000<$ 0,05 maka $\mathrm{H}_{1}$ diterima dan $\mathrm{H}_{0}$ ditolak, dan variabel $\mathrm{Xl}$ mempunyai $\mathrm{t}$ hitung $=4,310>\mathrm{t}$ tabel $=1,995$ dinyatakan bahwa variabel $\mathrm{Xl}$ mempunyai kontribusi terhadap Y. Sehingga dapat disimpulkan, zakat produktif memiliki pengaruh terhadap peningkatan pendapatan masyarakat miskin pada Baznas Kota Gorontalo.

Variabel spirit kewirausahaan (X2) terhadap peningkatan pendapatan masyarakatmiskin (Y), diperoleh nilai sig 0,001 lebih kecil dari nilai probabilitas 0,05 atau 0,00k 0,05 maka $\mathrm{H}_{1}$ diterima dan $\mathrm{H}_{0}$ ditolak, dan variabel X2 mempunyai t hitung $=3,352$ dan t tabel $=1,995$ atau 3,352>1,995 dinyatakan X2 mempunyai kontribusi terhadap Y. Sehingga dapat disimpulkan, minat berwirausaha memiliki pengaruh terhadap peningkatan pendapatan masyarakat miskin.

b. Pada tabel di atas menunjukkan bahwa nilai $\mathrm{R}$ Squere adalah 0,341 atau $34,1 \%$. Hal ini berarti bahwa besarnya koefisien determinasi tersebut menunjukkan bahwa zakat produktif dan minat berwirausaha memiliki kontribusi 
c. sebesar $34,1 \%$ terhadap peningkatan pendapatan masyarakat miskin pada Baznas Kota Gorontalo sedangkan sisanya sebesar 65,9\% (100\% $34,1 \%$ ditentukan atau dijelaskan oleh variabel lain.

d. Uji f digunakan untuk menguji pengaruh secara simultan variabel indpenden terhadap variabel dependennya, diperoleh $\mathrm{f}$ hitung $=17,597$ dengan tingkat signifikan 0,000 dan $\mathrm{f}$ tabel $=3,13$ dengan tingkat signifikan 5\%. Maka ini berarti f hitung memiliki nilai yang lebih besar dari f tabel sehingga $\mathrm{H}_{0}$ ditolak dan $\mathrm{H}_{1}$ diterima. Dengan demikian secara simultan terdapat pengaruh secara signifikan antara zakat produktif $(\mathrm{Xl})$ dan minat berwirausaha (X2) terhadap peningkatan pendapatan masyarakat miskin (Y).

\section{F. Diskusi Hasil Penelitian}

1. Pengaruh Zakat Produktif Terhadap Peningkatan

Pendapatan Masyarakat Pada Baznas Kota Gorontalo

Hasil penelitian ini membuktikan bahwa zakat produktif berpengaruh terhadap peningkatan pendapatan masyarakat pada Baznas Kota Gorontalo. Hal tersebut dapat dilihat dari hasil uji t yang diperoleh hasil thitung sebesar 4,310 lebih besar dari tabel1,995, dengan tingkat signifikan sebesar 0,000 lebih kecil dari 0,05. Hal Ini berarti variabel zakat produktif berpengaruh terhadap peningkatan pendapatan masyarakat. Karena dengan kaidah keputusanjika thitung lebih besar dari $t_{\text {tabel }}$ maka $\mathrm{H}_{0}$ ditolak dan $\mathrm{H}_{1}$ diterima, dan sebaliknya jika thitung lebih kecil dari $t_{\text {tabel }}$ maka $\mathrm{H}_{0}$ diterima dan $\mathrm{H}_{1}$ ditolak.

penelitian tersebut jika dilihat dari uji hipotesis yang diperoleh nilai koefisien zakat produktif sebesar 0,636, hal ini berarti jika zakat produktif ditingkatkan maka peningkatan pendapatan masyarakat miskin meningkat sebesar 0,636. Jadi dapat disimpulakan bahwa besar pengaruh zakat produktif terhadap peningkatan pendapatan masyarakat miskin adalah 0,636 atau $63,6 \%$.

\section{Pengaruh Minat Berwirausaha} Terhadap Peningkatan Pendapatan Masyarakat Miskin

Hasil penelitian ini membuktikan bahwa minat berwirausaha berpengaruh secara positif dan signifikan terhadap peningkatan pendapatan masyarakat miskin, hal ini dapat dilihat dari uji t diperoleh hasil thitung sebesar 3,352 lebih besar dari tabel 1,995, dengan tingkat signifikansi sebesar 0,001 lebih kecil dari 0,05. Ini menunjukkan bahwa variabel minat berwirausaha berpengaruh terhadap peningkatan pendapatan masyarakat miskin, karena dengan kaidah keputusan jika thitung lebih besar dari tabelmaka $\mathrm{H}_{0}$ ditolak dan $\mathrm{H}_{1}$ diterima, dan sebaliknya jika thitung lebih kecil dari $\mathrm{t}_{\text {tabel }}$ maka $\mathrm{H}_{0}$ diterima dan $\mathrm{H}_{1}$ ditolak.

Hasil tersebut jika dilihat dari uji hipotesis yang diperoleh nilai koefisien minat berwirausaha sebesar 0,329, hal ini berarti jika minat berwirausahaditingkatkan maka peningkatan pendapatan masyarakat miskinPada Baznas Kota Gorontalo meningkat sebesar 0,329. Jadi dapat disimpulkan bahwa besar pengaruh minat berwirausaha terhadap peningkatan pendapatan masyarakat adalah 0,329 atau 32,9\%. Hal ini dapat diartikan bahwa minat berwirausaha dalam hal ini bisa meningkatkan pendapatan masyarakat miskin karena semakin tinggi minat berwirausaha seseorang maka pendapatannya juga meningkat. 
3. Pengaruh Zakat Produktif dan minat berwirausaha Terhadap Peningkatan Pendapatan Masyarakat Miskin Pada Baznas Kota Gorontalo

Dalam perhitungan mencari besarnya pengaruh Zakat Produktif dan minat berwirausaha Terhadap Peningkatan Pendapatan Masyarakat Miskin Pada Baznas Kota Gorontalo, menunjukkan adanya pengaruh yang signifikan. Terbukti dari analisis yang diperoleh yaitu $F_{\text {hitung sebesar 17,597 }}$ dengan tingkat signifikan 0,000 dan $F_{\text {tabel }}=3,13$ dengan tingkat signifikan 0,05 , dan berdasarkan persamaan regresi berganda yang diperoleh dimana koefisien regeresi $X_{1}$ dan $X_{2}$ adalah positif maka dapat diartikan bahwa terdapat pengaruh yang positif antara variabel zakat produktif dan variabel minat berwirausaha terhadap peningkatan pendapatan masyarakat miskin pada Baznas Kota Gorontalo. Bentuk pengaruh yang diperoleh dari persamaan tersebut adalah jika variabel zakat produktif dan minat berwirausaha ditingkatkan sebesar satu point maka akan diikuti dengan meningkatnya pendapatan masyarakat masing-masing sebesar $0,636 \mathrm{X}_{1}$ dan $0,329 \mathrm{X}_{2}$

$\begin{array}{ccc}\text { Besarnya pengaruh zakat } \\ \text { produktif } & \text { dan } & \text { minat }\end{array}$
berwirausahaterhadap peningkatan pendapatan masyarakat miskin pada Baznas Kota Gorontalo dilihat pada nilai R Square yaitu sebesar 0,341 atau 34,1\%. Hal ini menunjukkan bahwa zakat produktif dan minat berwirausaha berpengaruh terhadap peningkatan pendapatan masyarakat miskin sebesar $34,1 \%$, sedangkan sisanya sebesar 56,9\% dipengaruhi oleh variabel lain yang tidak diteliti dalam penelitian ini.Adapun variabel lain yang tidak diteliti dalam penelitian ini yaitu pelatihan khusus dari lembaga Baznas kepada masyarakat miskin yang menerima bantuan untuk bagaimana mengelola dana zakat yang telah disalurkan, karena dalam penyaluran bantuan zakat produktif lembaga baznas hanya mengadakan sosialisasi.

\section{G. Kesimpulan}

1. Zakat Produktif, berpengaruh positif dan signifikan terhadap peningkatan pendapatan masyarakat miskin pada Baznas Kota Gorontalo. Hasil ini ditunjukkan pada perhitungan uji $\mathrm{t}$, terlihat bahwa zakat produktif memiliki nilait ${ }_{\text {hitung }}>t_{\text {tabel }}(4,310>$ 1,995) dengan nilai signifikan sebesar 0,000 yang lebih kecil dari 0,05 atau $(0,000<0,05)$ dan juga hasil perhitungan koefisien regresi sebesar 0,636. Artinya bahwa zakat produktif berpengaruh positiif terhadap peningkatan pendapatan masyarakat miskin pada Baznas Kota Gorontalo sebesar 0,636 atau 63,6\%.

2. Minat berwirausaha berpengaruh positif dan signifikan terhadap peningkatan pendapatan masayarakat miskin pada Baznas Kota Gorontalo. Hasil ini ditunjukkan pada perhitungan uji $t$, terlihat bahwa minat berwirausaha memiliki nilaithitung ttabel $(3,352>1,995)$ dengan nilai signifikan sebesar 0,001 yang lebih kecil dari 0,05 atau $(0,001<0,05)$ dan juga hasil koefisen regresi sebesar 0,329. Artinya bahwa minat berwirausaha berpengaruh positif terhadap peningkatan pendapatan masyarakat miskin pada Baznas Kota Gorontalo sebesar 0,329 atau 32,9\%

3. Zakat produktif dan minat berwirausaha secara simultan berpengaruh positif dan signifikan terhadap peningkatan pendapatan masayarakat miskin pada Baznas KotaGorontalo. Hal ini diperoleh dari hasil uji f yaitu fhitung sebesar 
17,597 dengan tingkat signifikan 0,000 dan $f_{\text {tabel }}=3,13$ dengan tingkat signifikan 0,05 , dan juga nilai $R$ Square sebesar 0,341 atau $34,1 \%$. Dalam hal ini diartikan bahwa zakat produktif dan berwirausaha berpengaruh terhadap peningkatan pendapatan masyarakat miskin sebesar 34,1\%, sedangkan sisanya sebesar 65,9\% dipengaruhi oleh variabel lain yang tidak diteliti dalam penelitian ini.

\section{DAFTAR PUSTAKA}

Al-Quran dan Terjemahnya, Departeman Agama RI, Spesial for Women, (Bandung : Syamil Al-Quran, 2007).

Abduracchman Qadir, (2001), Zakat dalam Dimensi Mahdah dan Sosial, Cet.2, (Jakarta: PT Raja Grafindo Persada).

Abi Abdillah bin Ismail, Shahih Bukhori, Beirut: Dar Kutub al Ilmiah, 1996, hal. 430 dalam eprints.walisobgo.ac.id diakses 25 Juni 2017.

Adel Hikam Arif, 2016, Pengaruh Zakat Produktif Terhadap Peningkatan Keluarga Miskin (Studi Kasus Pada Lembaga Amil Zakat El-Zawa UIN Maulana Malik Ibrahim): Fakultas Ekonomi dan Bisnis.

Adhe Octavionica, Pengaruh Motivasi Berwirausaha Serta Lingkungan Internal Dan Lingkungan Eksternal Terhadap Minat Berwirausaha Mahasiswa Pendidikan Ekonomi Universitas Lampung, Fakultas Keguruan Dan Ilmu Pendidikan Universitas Lampung Bandar Lampung 2016.
Adi Sasono, dkk., Solusi Islam Atas Problematika Umat: Ekonomi, Pendidikan dan Dakwah, cet ke-1, (Jakarta: Gema Insani Press, 1998).

Ali Khomsan dkk, Indikator Kemiskinan dan isklasifikasi Orang Miskin, Cet:1, (Jakarta: Yayasan Pustaka Obor Indonesia, 2015).

Armiadi,. Zakat Produktif: Solusi Alternatif Pemberdayaan Ekonomi Umat (Potret dan Praktek Baitul Mal Aceh), Cet. I, (Yogyakarta: ArRaniry Press Darussalam Banda Aceh \& AK GROUP Yogyakarta. 2008.

Garry Nugraha Winoto. 2011. Pengaruh Dana Zakat Produktif Terhadap Keuntungan Usaha Mustahik Penerima Zakat (Studi Kasus BAZ Kota Semarang). Semarang: Fakultas Ekonomi Universitas Diponegoro.

JESTT Vol. 1 No. 9 September 2014 di akses 25 Maret 2017.

K.N. Sofyan Hasan, Pengantar Hukum Zakat dan Wakaf, (Surabaya: AlIkhlas, 1995).

Mila Sartika, Pengaruh Pendayagunaan Zakat Produktif terhadap Pemberdayaan Mustahik pada LAZ Yayasan Solo Peduli Surakarta.

Moh. Thoriquddin, Pengelolaan Zakat Produktif Perspektif Maqasid AlSyari'ah Ibnu 'Asyur, Cet.l (UIN Maliki Press, 2015).

Muhammad Daud Ali, Sistem Ekonomi Islam Zakat dan Wakaf, Cet. Pertama, (Jakarta: UI-PRESS).

Milton Friedman, Quantity Theory of Money, 1956 dalam Ali Nugraha dan Yeni Rachmawati, Metode 
Pengembangan SosialEmosional. (Jakarta: Universitas Terbuka, 2008) .

Nasrullah, Regulasi Zakat \& Penerapan Zakat Produktif Sebagai Penunjang Pemberdayaan Masyarakat (Studi Kasus Pada Baitul Mal Kab. Aceh Utara), Vol. 9, No. 1, Juni 2015.

Purwanto Ngalim, Psikologi Pendidikan. (Bandung: PT Remaja Rosdakarya, 2006), h. 56

Richard H. Leftwich, Mikro Ekonomi, (Jakarta: Bina Aksara, 1984) hlm. 33 dalam skripsi Hafidoh 2015, Pngaruh Pemafaatan Dana Zakat Produktif Terhadap Tingkat Penghasilan Mustahik di Pos Keadilan Peduli Umat (PKPU) Yogyakarta, Fakultas Dakwah dan Komunikasi UIN Sunan Kalijaga.

Slameto, Belajar \& Faktor-Faktor yang Mempengaruhinya, (Jakarta: Rineka Cipta, 2010).

Sadono Sukirno, Makroekonomi. (Jakarta: Raja Grafindo Persada, 2004) hal. 84 dalam Sri Essa

(SHU) di Koperasi Karyawan Qualiti Sejahtera Kec. Kota Timur. Skripsi. Gorontalo: Fakultas Syariah
Ramadhani, 2010. Dampak Penyaluran Dana Bergulir Usaha Mikro Terhadap Peningkatan Pendapatan Pengusaha Mikro (Studi Kasus Industri Mikro di Kota Payakumbuh). Tesis: Pascasarjana Universitas Indonesia Jakarta.

Susanti Ridji Karim. 2012. Pengauh Pendapatan Masyarakat Petani Dan Nelayan Terhadap Tingkat Kesejahteraan Masyarakat Desa Bulota Kec. Telaga Jaya Kab. Gorontalo. Skripsi. Gorontalo: Fakultas Syariah Dan Ekonomi Islam.

ThoriquddinMoh., Pengelolaan Zakat Produktif Perspektif Maqasid AlSyari'ah Ibnu Asyur, Cet.l (UIN Maliki Press, 2015).

Winkel, W. S. Psikologi Pendidikan dan Evaluasi Belajar. Jakarta: PT. Gramedia Pustaka Utama 2004.

Yulin Hango. 2012. Pengeruh Pendapatan Unit Usaha Waserda dan Simpan Pinjam Terhadap Perolehan Sisa Hasil Usaha dan Ekonomi Islam IAIN Sultan Amai Gorontalo. 